Banco, Volume 1, November 2019

\title{
STRATEGI MINDSET ENGLISH CENTER PAREPARE PERSPEKTIF MANAJEMEN SYARIAH
}

\author{
Rubiah \\ IAIN Parepare \\ rubiah21@iainparepare.ac.id
}

Moh. Yasin Soumena

IAIN Parepare

yasin@iainparepare.ac.id

\author{
Abdul Hamid \\ IAIN Parepare \\ hamid@iainparepare.ac.id
}

\begin{abstract}
This research is a qualitative research using a sociological normative approach. Data were collected using observation and interview methods. Data analysis technique used is to reduce data, present data and draw conclusions.

The results of this study can be stated that 1) Strategic planning of the Parepare English Center Mindset can help, assist and ease the cost of English courses. 2) Implementation of the Parepare Mind Center English Center strategy, which means that participants can make payments easier. 3) Evaluate the Parepare Mind Center English Center strategy to run effectively and efficiently. If this is related to sharia management, it is in accordance with the principles of sharia management, namely justice, trustworthiness and accountability, as well as communicative.
\end{abstract}

Keywords: Strategy, Mindset English Center, Syariah Manajement, Course

\begin{abstract}
Abstrak
Penelitian ini merupakan penelitian kualitatif menggunakan pendekatan normatif sosiologis dan dalam mengumpulkan data menggunakan metode observasi dan wawancara. Tekhnik analisis data yang digunakan yaitu dengan mereduksi data, menyajikan data dan penarikan kesimpulan.

Hasil penelitian ini dapat dikemukakan bahwa 1) Perencanaan strategi Mindset English Center Parepare dapat menolong, membantu dan meringankan biaya kursus Bahasa Inggris. 2) Implementasi strategi Mindset English
\end{abstract}


Center Parepare yakni peserta dimudahkan dalam pembayaran. 3) Evaluasi strategi Mindset English Center Parepare berjalan efektif dan efisien. Jika hal ini dikaitkan dengan manajemen syariah maka hal ini sesuai dengan prinsipprinsip manajemen syariah yakni keadilan, amanah dan pertanggungjawaban serta komunikatif

Kata kunci : Strategi, Mindset English Center, Manajemen Syariah, Kursus Bahasa

\section{A. Pendahuluan}

Era globalisasi mengakibatkan banyak kemajuan dalam berbagai bidang, di antaranya dalam dunia perdagangan bebas. Banyak perusahaan-perusahaan asing didirikan di dalam negeri. Dalam hal berbisnis, komunikasi merupakan faktor pendukung yang paling utama, ketidakfasihan seseorang dalam menggunakan Bahasa Inggris dapat menghambat interaksi dalam kegiatannya. Maka dari itu, Bahasa Inggris sangat penting untuk dikuasai agar dapat bersaing dengan pihak lain. Allah berfirman dalam Q.S. Ibrahim/14: 4.

Kami tidak mengutus seorang rasulpun, melainkan dengan bahasa kaumnya supaya ia dapat memberi penjelasan dengan terang kepada mereka. Maka Allah menyesatkan siapa yang dia kehendaki, dan memberi petunjuk. kepada siapa yang dia kehendaki. dan Dia-lah Tuhan yang Maha Kuasa lagi Maha Bijaksana'.

Ayat di atas menjelaskan bahwa penggunaan bahasa dalam berkomunikasi sangatlah penting. Sama halnya dengan Bahasa Arab yang dimaksud dalam ayat di atas. Bahasa Inggris juga dapat dikatakan ibu dari berbagai bahasa. Artinya, Bahasa Inggris adalah Bahasa Internasional yang dapat menghubungkan komunikasi antarnegara, sehingga Bahasa Inggris di masa sekarang dan di masa akan datang menjadi prioritas digunakan di masyarakat.

Dalam dunia bisnis, Bahasa Inggris sangat berperan terutama jika saat menjalin kerjasama dengan perusahaan asing. Di dunia usaha yang semakin mengglobal, semakin banyak perusahaan lokal termasuk perusahaan Indonesia telah masuk ke pasar dunia. Penggunaan Bahasa Inggris yang menjadi bahasa bisnis semakin dirasakan sebagai suatu keharusan. Selain itu, terlihat banyak sekali kasus di mana seringkali negosiasi gagal karena salah paham dengan mitra asing. Pekerjaan tertunda karena komunikasi yang terbata-bata mengakibatkan lamaran kerja di sebuah perusahaan asing ditolak karena kemampuan berbahasa Inggris yang kurang. Maka dari itu, Bahasa Inggris sangat penting untuk diketahui demi meningkatkan mutu kualitas diri agar dapat bersaing di dunia internasional terutama dalam dunia bisnis².

Mindset English Center Parepare merupakan sebuah lembaga yang menggabungkan antara edukasi dan entertainment. Awal berdirinya Mindset English Center Parepare adalah wadah pengembangan kemampuan berbahasa Inggris dan pengembangan karakter pribadi generasi Indonesia.

Pencapaian tujuan dan perkembangan Mindset English Center Parepare menggunakan salah satu tahap pengembangan lembaga yaitu tahap manajemen strategi yang meliputi pengamatan lingkungan, perencanaan strategi, implementasi strategi dan evaluasi. Bagi organisasi bisnis, strategi dimaksudkan untuk mempertahankan keberlangsungan bisnis perusahaan dibandingkan para persaingnya dalam memenuhi kebutuhan konsumen. Sebuah perusahaan melakukan strategi untuk memenangkan persaingan bisnis yang dijalankannya, serta untuk mempertahankan keberlangsungan kehidupan perusahaan dalam jangka penjang.

1Departemen Agama RI, Al-Qur'an dan Terjemahnya (Bandung: CV Penerbit Diponegoro, 2010), h. 255.

Juwita Aromm, Pentingnya Menuasai Bahasa Inggris dalam Berbagai Bidang, http://juwitaaroem.blogspot.co.id/2014/05/pentingnya-menguasai-bahasa-inggris.html?m=1 (07 April 2017). 


\section{Rubiah, Moh. Yasin Soumena, Abdul Hamid}

Strategi dalam manajemen merupakan suatu proses yang dinamik karena ia berlangsung secara terus menerus dalam suatu organisasi. Setiap strategi selalu memerlukan peninjauan ulang dan bahkan mungkin perubahan di masa depan. Salah satu alasan utama mengapa demikian halnya adalah kerena kondisi yang selalu berubah-ubah pula. Dengan perkataan lain, manajemen strategi dimaksudkan agar organisasi menjadi satuan yang mampu menampilkan kinerja tinggi karena organisasi yang berhasil adalah organisasi yang tingkat efektivitas dan produktivitasnya makin lama makin tinggi. Hanya dengan demikianlah, tujuan dan berbagai sasarannya dapat tercapai dengan hasil yang memuaskan.

Perkembangan Mindset English Center Parepare mulai terlihat dari tahun ke tahun setelah menerapkan manajemen strategi dengan menghadirkan inovasi baru. Gaya hidup (lifestyle) adalah bagian dari kebutuhan sakunder manusia yang biasa berubah tergantung dari zaman ${ }^{3}$. Melihat perubahan gaya hidup di masa sekarang, cafe merupakan salah satu tempat yang sangat gemar dikunjungi remaja. Mindset English Center Parepare menghadirkan cafe sebagai daya tarik konsumen, namun tujuan utama lembega tersebut tetap pada bimbingan Bahasa Inggris. Salah satu produk bimbingan Bahasa Inggris Mindset English Center Parepare adalah bimbingan atau kursus seumur hidup, di mana seseorang yang ingin mendaftar hanya membayar Rp 1.500.000 untuk mendapatkan bimbingan seumur hidup, dan produk ini mampu menarik perhatian para konsumen pengguna jasa.

Penelitian ini dilatarbelakangi oleh suatu pemikiran bahwa semua organisasi baik yang berbentuk badan usaha swasta, badan yang bersifat publik ataupun lembaga-lembaga sosial kemasyarakatan, tentu mempuanyai tujuan tersendiri yang merupakan motivasi dari pendiriannya.

Pada penelitian ini, Peneliti ingin mengetahui mengenai manajemen strategi lembaga tersebut dan juga menganalisis apakah manajemen strategi yang digunakan telah sesuai dengan sistem manajemen syariah.

\section{B. Diskusi dan Pembahasan}

\section{Gambaran Umum dan Profil Penelitian}

Mindset Englis Center Parepare merupakan salah satu cabang dari perusahaan induk PT. Mindset Elang Cendekia Indonesia yang merupakan pusat "Edutainment" terbesar di Indonesia menggabungkan antara edukasi dan intertainment. PT. Mindset Elang Cendekia Indonesia didirikan pada hari Sabtu, 26 Februari 2011 oleh Mr. Muhammad Eka Prachandra yang merupakan alumni Universitas Negeri Makassar.

PT. Mindset Elang Cendekia Indonesia merupakan perusahaan induk yang menaungi banyak anak perusahaan antara lain Mindcet English Center, Mindcet English Cafe dan Mindset English Photo Kopi. PT. Mindset Elang Cendekia memiliki beberapa cabang di Indonesia antara lain:
a. MEC Cabang Ratulangi di Makassar
b. MEC Cabang Malengkiri di Makassar
c. MEC Cabang BTP di Makassar
d. MEC Adiaksa di Makassar
e. MEC Cabang Maros
f. MEC Cabang Pangkep
g. MEC Cabang Parepare
h. MEC Cabang Pinrang
i. MEC Cabang Sidrap
j. MEC Cabang Palopo

${ }^{3}$ Wikipedia, Gaya Hidup, https://id.m.wikepedia.org/wiki/Gaya hidup (7 April 2017). 
k. MEC Cabang Sengkang

1. MEC Cabang Bone

m. MEC Cabang Palu yang terdiri dari 2 cabang

n. MEC Cabang Bogor

o. MEC Cabang Samarinda

p. MEC Cabang Palembang

q. MEC Cabang Malang

r. MEC Cabang Kediri

s. MEC Cabang Bulukumba

t. MEC Cabang Sinjai

u. MEC Cabang Kendari

v. MEC Cabang Balikpapan

Sejak berdiri higgah sekarang, ada banyak penghargaan yang telah dicapai PT. Mindset Elang Cendekia Indonesia, yaitu: menjadi salah satu juara WMM (Wirausaha Muda Mandiri) tahun 2013 mewakili Indonesia Timur, menjadi salah satu sponsor dan terpilih menjadi tim penulis soundtrack "Uang Panai" bersama Dheandra Band, Gathering lebih dari 1000 member se-Sulawesi Selatan di tahun 2016 dan dimeriakan oleh Sheila On 7, pada tahun 2017 tepatnya di ulang tahun ke-5 PT. Mindset Elang Cendekia Indonesia berhasil sosialisasi 6000 member secara bersamaan dan acara tersebut dimeriakan oleh Musikmia Dheandra dan juga Tumming Abu, berhasil membentuk MEC Komunitas sebagai komunitas Bahasa Inggris terbesar se-Indonesia, telah hadir di empat pulau (Sulawesi, Jawa, Kalimantan dan Sumatra) dan 22 cabang se-Indonesia, dan masih banyak pencapaian lainnya.

Pusat bimbingan belajar Bahasa Inggris PT. Mindset Elang Cendekia Indonesia membuka cabang di Kota Parepare yaitu Mindset English Center Parepare pada tahun 2016. pertama dibuka di Jalan Kebun Sayur kemudian berpindah tempat di Jl. Andi Makkasau dan sekarang beralamat di Jalan Laupe no. 79 Kec. Soreang Kota Parepare. Mindset English Center Parepare merupakan cabang ke 17 dari 22 cabang tersebar di Indonesia.

\section{Perencanaan Strategi Mindset English Center Parepare Dalam Pencapaian Tujuan}

Dalam organisasi atau lembaga, perencanaan strategi terjadi baik di kantor pusat maupun unit bisnis. Manajer yang paling kompeten harus menghabiskan waktu yang cukup lama untuk memikirkan mengenai masa depan organisasi atau lembaga. Hasil yang mungkin merupakan pemahaman informal mengenai arah masa depan yang akan diambil oleh entatitas tersebut atau yang berupa pernyataan formal yang beris rencana sfesifik mengenai bagaimana untuk sampai pada suatu arah.

Karakteristik dari perencanaan strategi adalah proses memutuskan program-program yang akan dilaksanakan organisasi dan perkiraan jumlah sumber daya yang akan dialokasikan ke setiap program selama beberapa tahun kedepan. Perencanan strategi sebagai upaya yang membuat keputusan dan tindakan penting yang membentuk dan memandu bagaimana menjadi organisasi, apa yang dikerjakan organisasi dan mengapa organisasi mengerjakan hal seperti itu.

Dalam menjalankan bisnis, perusahaan akan dihadapkan pada banyak tantangan, di antaranya munculnya pesaing dengan bisnis yang serupa. Banyaknya pesaing membuat pelaku bisnis merasa cemas apalagi jika startegi pesaing jauh lebih bagus dan matang. Hal ini mendorong perusahaan untuk menciptakan terebosan baru untuk menarik minat pelanggan sehingga perusahan tersebut dapat 


\section{Rubiah, Moh. Yasin Soumena, Abdul Hamid}

memenangkan persaingan dunia bisnis. Sama halnya dengan lembaga Mindset English Center Parepare yang memiliki banyak pesaing. Dalam menarik minat pelanggan, Mindset English Center Parepare hadir sebagai lembaga kursus Bahasa Inggris dengan memadukan antara edukasi dan intertaiment. Ada banyak produk dan macam model pembelajaran di Mindset English Center Parepare, salah satunya adalah program kursus seumur hidup.

Semua dasar dan tujuan manajemen harus terintegrasi, konsisten dan salain menunjang satu sama lain. Untuk menjaga konsisten ke arah tujuan pencapaian tujuan manajemen maka setiap usaha harus di dahului oleh proses perencanaan yang baik. Sebagaimana firman Allah Q.S. al-Hasyr/59: 18.

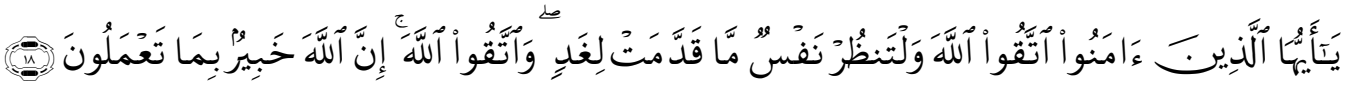

Terjemahnya :

Hai orang-orang yang beriman, bertakwalah kepada Allah dan hendaklah setiap diri memperbatikan apa yang Telah diperbuatnya untuk. hari esok (akhirat); dan bertakwalah kepada Allah, Sesungguhnya Allah Maha mengetahui apa yang kamu kerjakan. ${ }^{4}$

Suatu perencanaan yang baik dilakukan melalui berbagai proses kegiatan yang meliputi forecasting, objektif, policies, programes, prosedures dan budget.

Forecasting suatu pemahaman usaha yang sistematis, yang paling mungkin memperoleh sesuatu di masa yang akan datang dengan dasar penaksiran dan menggunakan perhitungan yang rasional atas fakta yang ada. Fungsi perkiraan yaitu memberi informasi sebagai dasar pertimbangan dalam pengambilan keputusan. Sebagimana dalam perencanaan program kursus seumur hidup Mindset English Center Parepare menyediakan jasa kursus Bahasa Inggris seumur hidup dengan pembiayaan sekali selama kursus hingga mampu berbahasa Inggris. Hal ini dikemukakan Owner Mindset English Center Mr. Muhammad Eka Prachandra dalam penyambutannya saat meresmikan Mindset English Center Cabang Kendari, sebagai berikut :

Program muncul dipikiran saya ketika saya menghadiri suatu pertemuan internasional bertemu dan seorang anak yang ingin berkomunikasi dengan bangsa asing yang hadir di kegiatan tersebut namun ia tidak mampu mampu berbahasa Inggris. Saya tanya anak itu, kenapa ngga kursus dek ? ia jawab biaya kursus mahal mas. Saat itulah saya memikirkan program kursus seumur hidup dengan sekali bayar. ${ }^{5}$

Manajer yang berpengalaman tidak jarang memperkirakan sesuatu berdasarkan intusi. Hal ini juga dapat bersumber dari taufiq dan hidayah Allah bagi mereka yang dikehendaki-Nya. Dalam menghadapi persoalan yang musykil meminta petunjuk kepada Allah untuk mendapatkan petunjuk dan hidayah-Nya dalam mengambil keputusan dan merencanakan sesuatu. Sikap ini akan membawa kepada sikap taqarrub kepada Allah dan membiasakan diri untuk tidaka mengambil tindakan yang gegabah dalam segala hal.

Objective atau tujuan adalah nilai yang akan dicapai dan diinginkan oleh seorang atau badan usaha. Untuk mencapai tujuan, bersedia memberi pengorbanan atau usaha yang wajar. Tujuan organisasi atau lembaga harus dirumuskan secara jelas, realitas dan dapat diketahui oleh yang terlibat dalam organisasi, agar semua dapat berpartisipasi dengan penuh kesadaran. Program kursus seumur hidup merupakan

${ }^{4}$ Departemen Agama RI, Al-Qur'an dan Terjemahnya, h. 547.

${ }^{5}$ Hasil Wawancara Mr. Muhammad Eka Prachandra, selaku Owner Mindset English Center Parepare, Tanggal 12 Juli 2017 
perencanan strategi Mindset English Center Parepare sesuai visi misi dan pencapaian tujuan di mana memberikan keluasan kepada member belajar Bahasa Inggris tanpa terikat oleh waktu. Program tersebut sudah ditawarkan dan berjalan disemua Cabang Mindset English Center di Indonesia. Hal ini sebagai mana yang dikatakan Mr. Adri Aladin, Mr. Kasim dan Mr. Hadi sebagai berikut :

Program kursus seumur hidup merupakan program yang sudah ada dan ditawarkan sejak lembaga kursus Mindset English Center terbentuk. Program ini menarik banyak perhatian masyarakat terkhusus bagi siswa pelajar yang mendengarkan langsung sosialisasi tentang program ini. Tujuan dari program ini adalah mencerdaskan bangsa dengan menawarkan jasa kursus Bahasa Inggris yang lebih murah sehingga terjangkau bagi semua kalangan. ${ }^{6}$

Program kursus seumur hidup sudah ada sejak bergabung Mindset English Center Parepare pada tahun 2015. Program ini telah berjalan diseluruh cabang termasuk cabang di Parepare. ${ }^{7}$

Program kursus seumur hidup merupakan produk utama pada lembaga kursus ini. Awalnya program ini didesain untuk member yang berada di luar daerah, walaupun member tersebut berada di luar daerah ia juga berhak mengikuti kursus pada cabang MEC di daerah tersebut dengan catatan memperlihatkan kartu member. ${ }^{8}$

Policies dapat berarti rencana kegiatan (plan of action) atau juga dapat diartikan sebagai suatu pedoman pokok (guiding principles) yang diadakan oleh suatu badan usaha untuk menentukan kegiatan yang berulang-ulang. Keputusan mengenai suatu policies ditentukan oleh manajemen puncak atau chief excecutive officer atau board of directors dari suatu badan usaha. Selain menawarkan program kursus seumur hidup Mindset English Center parepare sebagai lembaga yang menggabungkan antara edukasi dengan intertaiment hadir dengan terebosan baru. Di Kota Parepare Mindset English Center mengkonsepkan area pembelajarannya ala cafe untuk para pelajar, dengan alasan belajar dengan santai akan lebih efektif dan efisien. Hal ini sebagaimana yang dikatakan branch manager Mindset English Center Parepare Mr. Adri Aladin, sebagai berikut :

Konsep bimbingan belajar Mindset English Center Parepare diatur semenarik mungkin dengan menghadirkan kafe sebagai tempat belajar. Hal itu dimaksudkan untuk memberikan kesan santai dan rileks selama proses bimbingan atau pembelajaran, dan konsep ini akan menjadi daya tarik tersendiri. karena biasanya orang kalau ke cafe itu cuman nongkrong-nongkrong tidak jelas trus pulang, nah di MEC kami akan merubah kebiasaan itu. Nongkrong di cafe akan lebih bermanfaat dengan diskusi sejuta ilmu. ${ }^{9}$

Cafe menjadi tempat yang menjamur di lingkuan sekitar kota dalam beberapa tahun belakangan ini. Melihat hal ini muncul idea menciptakan suasana baru, menjadikan cafe sebagai tempat belajar yang seruh, sehinggah member dijamin tidak akan bosan apalagi jenuh saat belajar. ${ }^{10}$

Ada banyak cara atau strategi yang bisa dilakukan dalam menarik minat pelanggan seperti halnya di Mindset English Center Parepare memanfaatkan cafe sebagai daya tarik, memberikan berbagai potongan harga serta memberikan berbagai macam fasilitas, diantaranya :

a. Sekali bayar, program selamanya

${ }^{6}$ Hasil Wawancara Mr. Adri Aladin, selaku Branch Manager Mindset English Center Parepare, Tanggal 12 Juli 2017.

${ }^{7}$ Hasil Wawancara Mr. Muh. Kasim, selaku Trainer Mindset English Center Parepare, Tanggal 12 Juli 2017.

${ }^{8}$ Hasil Wawancara Mr. Hadi Arif, selaku Branch Manager Mindset English Center Pinrang, Tanggal 12 Juli 2017.

${ }^{9}$ Hasil Wawancara Mr. Adri Aladin, selaku Branch Manager Mindset English Center Parepare, Tanggal 12 Juli 2017.

${ }^{10}$ Hasil Wawancara Mr. Abd Rauf, selaku Marketing Mindset English Center Parepare, Tanggal 12 Juli 2017.

Banco, Volume 1, November 2019 


\section{Rubiah, Moh. Yasin Soumena, Abdul Hamid}

b. Garansi belajar diseluruh cabang MEC

c. Garansi mampu Berbahasa Inggris

d. Ruangan santai (fun room) cteative class

e. Pembelajaran private atau face to face di MEC English Caffee

Dari hasil wawancara dan infomasi di atas dapat disimpulkan bahwa hadirnya program kursus seumur hidup Mindset English Center Parepare dikalangan pelajar, telah banyak diminati. Karena dapat meringankan beban biaya serta memberikan suasana belajar yang nyaman dan santai.

Berdasarkan hasil wawancara yang dipaparkan di atas jika dikaitkan dengan manajemen syariah sudah sesuai, kareana tujuan hadirnya program kursus seumur hidup dapat membentu meringankan biaya dan tidak memberikan penekanan waktu dalam pembelajaran. Sebagaimana hasil wawancara dengan member Mindset English Center Parepare yang mengikuti program kursus seumur hidup, sebagai berikut :

Sebenarnya saya memilih program kursus seumur hidup di MEC dikarenakan hanya sekali melakukan pembayaran dan cara belajarnya yang santai. ${ }^{11}$

Dapat belajar Bahasa Inggris yang baik tanpa perlu berpikir tentang biaya karena hanya melakukan sekali pembayaran. ${ }^{12}$

Dari hasil wawancara dengan beberapa member di atas, terbukti bahwa program kursus seumur hidup Mindset English Center Parepare sangat memberikan manfaat dan tidak merugikan kalangan manapun karena didasarkan atas asas tolong-menolong. Bisnis yang benar-benar sukses menurut pandangan al-Quran adalah bisnis yang membewa keuntungan pada pelakunya. Dalam dua fase kehidupan manusia yang fana dan terbatas yakni dunia yang tidak abadi serta tidak terbatas, yaitu akhirat. Manusia harus bekerja bukan hanya untuk meraih sukses di dunia namun juga untuk kesuksesan di akhirat. Semua kerja seseorang akan mengalami efek yang demikian besar pada diri seseorang.

Manajemen yang baik harus memenuhi syarat-syarat yang tidak boleh ditinggalkan (conditio sine qua non) demi mencapai hasil yang baik. Oleh karena itu para penguasa dan pengusaha wajib mempelajari ilmu manajemen yang sesuai syari'at Islam. Tedapat beberapa prinsip manajemen syari'ah, yaitu: ${ }^{13}$

\section{a. Keadilan}

Meski benar bahwa keadilan dan ketidakadilan telah terlihat jelas semenjak manusia eksis di muka bumi, manusia masih kabur dalam menggambarkan tapal batasnya. Arti keadilan tidak pernah dipahami secara lengkap. Keadilan merupakan satu prinsip fundamental dalam ideologi Islam. Pengelolaan keadilan seharusnya tidak sepotong-potong, tanpa mengacu kepada status sosial, aset finansial, kelas dan keyakinan religius seseorang. Al-Qur'an telah memerintahkan penganutnya untuk mengambil keputusan dengan berpegang pada kesamaan derajat, keutuhan dan keterbukaan.

Kata kunci yang digunakan Al-Qur'an dalam menjelaskan konsep keadilan adalah 'adl dan qist. 'Adl mengandung pengertian sawiyyat, dan juga mengandung makna pemerataan dan kesamaan. Qist

\footnotetext{
${ }^{11}$ Hasil Wawancara Ms. Rosnawati Yusuf, selaku Member Mindset English Center Parepare, Tanggal 17 Juli 2017.

${ }^{12}$ Hasil Wawancara Ms. Hardiyanti SF, selaku Member Mindset English Center Parepare, Tanggal 17 Juli 2017.

${ }^{13}$ Muhammad, Manajemen Bank Syariah, h. 183.
} 
mengandung makna distribusi, ansuran, jarak yang merata. Sehingga kedua kata dalam Al-Qur'an yang digunakan untuk menyatakan keadilan yakni 'adl dan qist mengandung makna distribusi yang merata, termasuk distribusi materi.

Dalam pelaksanaan program kursus seumur hidup Mindset English Center Parepare dianggap sesuai dengan manajemen syariah. Di mana tuntutan hak yang di berikan sudah adil. Member mendapatkan kepuasan dari pelayanan all official mendapatkan haknya sesuai dengan tanggungjawabnya. Sebagaimana hasil wawancara dengan beberapa official Mindset English Center Parepare sebagai berikut :

"Dalam pelaksanaan program kursus seumur hidup Mindset English Center Parepare yah saya memang harus berlaku adil, adil dalam menimbang, bertindak apalagi menghukum atau memberi sangsi kepada official Mindset English Center Parepare. Adil dalam artian pengajar memberikan hak kepada bawaan saya setelah menyelesaikan tanggung jawab mereka". ${ }^{14}$

Hukum syariah mewajibkan menegakkan keadilan, kapan pun dan di mana pun, Allah berfirman dalam surah Q.S. An-Nisa 04/58.

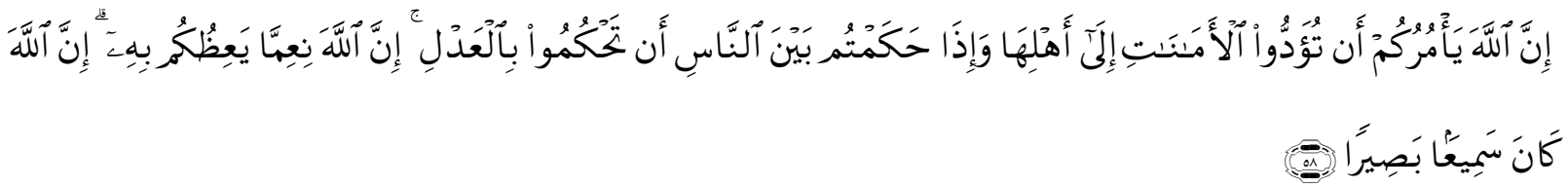

Terjemahnya :

Sesunggubnya Allab menyurub kamu menyampaikan amanat kepada yang berbak menerimanya, dan (menyurub kamu) apabila menetapkan bukum di antara manusia supaya kamu menetapkan dengan adil. Sesunggubnya Allah memberi pengajaran yang sebaik-baiknya kepadamu. Sesunggubnya Allah adalab Maha mendengar lagi Maha Melibat. ${ }^{15}$

\section{b. Amanah dan Pertanggungjawaban}

Dalam hal amanah dan pertanggungjawaban, Islam menggariskan dalam firman Allah Q.S. An-Nahl/16: 93.

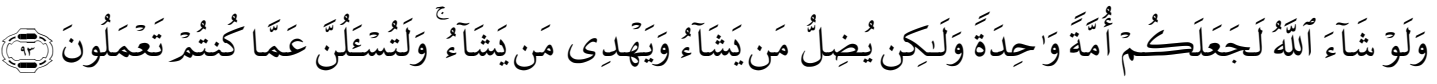

Terjemahnya:

Dan kalau Allah menghendaki, niscaya dia menjadikan kamu satu umat (saja), tetapi Allah menyesatkan siapa yang dikehendaki-Nya dan memberi petunjuk kepada siapa yang dikehendaki-Nya. dan Sesunggubnya kamu akan ditanya tentang apa yang Telab kamu kerjakan. ${ }^{16}$

Al-Maraghi mengklarifikasikan amanat terdiri atas tanggungjawab manusia kepada sesamanya, tanggungjawab manusia kepada Tuhan dan tanggungjawab manusia kepada dirinya sendiri. Prinsip tersebut bermakna bahwa setiap pribadi yang mempunyai kedudukan fungsional dan interaksi

\footnotetext{
${ }^{14}$ Hasil Wawancara Mr. Adri Aladin, selaku Branch Manager Mindset English Center Parepare, Tanggal 12 Juli 2017.

${ }^{15}$ Departemen Agama RI, Al-Qur'an dan Terjemahnya, h. 87.

${ }^{16}$ Departemen Agama RI, Al-Qur'an dan Terjemahnya, h. 277.
}

Banco, Volume 1, November 2019 


\section{Rubiah, Moh. Yasin Soumena, Abdul Hamid}

antarmanusia dituntut agar melaksanakan kewajibannya dengan sebaik-baiknya. Apabila ada kelalaian terhadap kewajiban tersebut akan mengakibatkan kerugian bagi dirinya sendiri.

Proses program kursus seumur hidup Mindset English Center Parepare memerlukan rasa tanggungjawab yang besar kepada para member. Memberikan pelayanan sesuai dengan apa yang dijanjikan. Prinsip tanggungjawab dirasa telah sesuai karena tanggungjawab dilakukan dengan penuh amanah. Hal ini sebagaimana hasil wawancara dengan beberapa member Mindset English Center Parepare sebagai berikut :

"Saya puas dengan apa yang telah saya dapatkan di MEC Parepare, banyak yeng sebelumnya tidak saya dapatkan di kampus, saya dapatkan di program kursus seumur hidup". ${ }^{17}$

"Saya sudah kursus selama empat bulan dan saya puas. Menurut saya official MEC yang menjalankan tanggungjawab saya merasa sudah mendapatkan hak yang dijanjikan pada saat sosialisasi. ${ }^{18 "}$

Dengan demikian jelas bahwa hak dan kewajiban seseorang dalan mamajemen secara tegas diatur dalam hukum Syariah.

\section{c. Komunikatif}

Sesungguhnya dalam setiap gerak manusia tidak dapat menghindari untuk berkomunikasi. Dalam manajemen komunikasi menjadi faktor yang penting dalam melakukan transformasi kebijakan atau keputusan dalam rangka pelaksanaan manajerial itu sendiri menuju tercapainya tujuan yang diharapkan. Begitu pentingnya komunikasi dalam manajemen, sehingga menuntut komunikasi tersebut disampaikan dengan tepat. Ketepatan penyampaian komunikasi ini, selanjutnya disebut sebagai komunikatif. Diantara ayat-ayat Al-Qur'an yang menjelaskan komunikasi yang komunikatif adalah Q.S. Thaaha/20: 44.

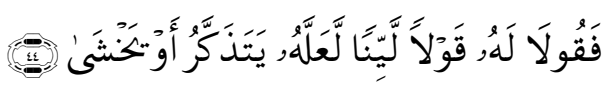

\section{Terjemahnya:}

Maka berbicaralah kamu berdua kepadanya dengan kata-kata yang lemah lembut, Mudah-mudahan ia ingat atau takut. ${ }^{19}$

Menurut Al-Maraghi, ayat tersebut terkait pembicaraan dengan Fir'aun yakni pembicaraan yang lemah lembut agar lebih dapat menyentuh hati dan lebih dapat menariknya untuk menerima dakwah. Sebab dengan perkataan yang lemah lembut, hati orang-orang yang durhaka akan menjadi halus dan kekuatan orang-orang yang sombong akan hancur.

Program kursus seumur hidup Mindset English Center Parepare dianggap sudak komunikatif, melihat metode pembelajaran yang digunakan efektif dan efisien lebih santai tapi tetap pada keseriusan. Interaksi trainer dan member berupa freetalk sehingga bisa membangun rasa kekeluargaan. Sebagaimana hasil wawancara dengan offcial Mindset English Center Parepare sebagai berikut :

\footnotetext{
${ }^{17}$ Hasil Wawancara Ms. Hera Adira, selaku Member Mindset English Center Parepare, Tanggal 12 Juli 2017.

${ }^{18}$ Hasil Wawancara Ms. Heriati Yunus, selaku Member Mindset English Center Parepare, Tanggal 12 Juli 2017.

${ }^{19}$ Departemen Agama RI, Al-Qur'an dan Terjemahnya, h. 314.
} 
Interaksi trainer dan member dalam pelaksanaan program kursus seumur hidup menggunakan metode free talk yang artinya selain trainer mampu mengajar dan mengetahui kemempuan member, trainer juga bisa mengetahui phscologi member program kursus seumur hidup. ${ }^{20}$

Interaksi yang terjadi antara trainer dan member berupa freetalk sehingga trainer dan member bisa membengun rasa kekeluargaan sehingga tidak ada lagi rasa tanggung antara keduanya. ${ }^{21}$

Tujuan hidup manusia sebagai tujuan manajemen, hal ini tidak terlepas dari firman Allah Q.S. adz-Dzariyaat/51: 56.

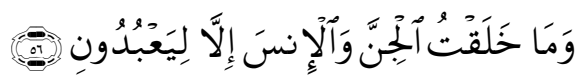

Terjemahnya :

Dan Aku tidak menciptakan jin dan manusia melainkan supaya mereka mengabdi kepada-Ku. ${ }^{22}$

Inilah tujuan hidup manusia menurut ajaran Allah Swt, yang berintikan tauhid (pengesaan Tuhan) diikuti dengan seruan agar manusia beriman dan cinta kepada Allah dan Rasulnya serta yakin akan adanya hari akhirat. Segala tindakan dan kegiatan manusia hendaknya dilandasi motivasi untuk memperoleh karidaan Allah, orientasinya kepada kebahagiaan akhirat (tanpa melupakan bagiannya di dunia) dan aplikasinya adalah ditegakkannya hukum syariah.

Bagi setiap Muslim, keridhan Allah adalah segala sumber dari kebahagiaan, di dunia dan di akhirat. Dunia adalah ladang tempat bertanam, hasil yang dinikmatinya di dunia adalah sebagian kecil saja dari hasil yang sesungguhnya diperoleh. Bagian hasil terbesar adalah kenikmatan yang akan didapatkan di akhirat.

\section{Implementasi Strategi Mindset English Center Parepare dalam Pencapaian Tujuan}

Salah satu strategi yang sering dilakukan pebisnis untuk menarik minat pelanggan adalah dengan memberikan potongan harga atau menawarkan produk dan jasanya dengan harga yang lebih rendah. Ada banyak produk dan model bimbingan yang ditawarkan Mindset English Center Parepare, salah satunya adalah program kursus seumur hidup hanya dengan biaya Rp 1.500.000. Hal ini sesuai dengan hasil wawancara sebagai berikut :

Program ini diperuntukkan bagi mereka yang tidak mampu akan finansial tapi ingin belajar Bahasa Inggris. Agar pembayaran tidak menjadi beban bagi peserta, jadi hanya sekali bayar selama mengikuti program kursus seumur hidup..$^{23}$

\footnotetext{
${ }^{20}$ Hasil Wawancara Ms. Salmi, selaku Trainer Cafe Mindset English Center Parepare, Tanggal 12 Juli 2017.

${ }^{21}$ Hasil Wawancara Ms. Salmi, selaku Trainer Cafe Mindset English Center Parepare, Tanggal 12 Juli 2017.

22 Departemen Agama RI, Al-Qur'an dan Terjemahnya, h. 523.

${ }^{23}$ Hasil Wawancara Mr. Adri Aladin, selaku Branch Manager Mindset English Center Parepare, Tanggal 12 Juli 2017.
}

Banco, Volume 1, November 2019 


\section{Rubiah, Moh. Yasin Soumena, Abdul Hamid}

Saya memilih kursus seumur hidup di MEC karena tidak lagi dibebani pembayaran perbulan seperti kursusan-kursusan yang saya ikuti sebelumnya, hanya sekali membayar dapat belajar Bahasa Inggris dengan baik tanpa perlu berpikir tentang biaya. ${ }^{24}$

Saya memilih mengikuti program kursus seumur hidup MEC karena dengan saya ikut program tersebut saya bisa belajar hingga batas akhir dan tidak memikirkan biaya bulan lagi, lebih hemat biayalah....25

Motode yang diterapkan dalam program kursus seumur hidup di Mindset English Center Parepare adalah memberikan bimbingan belajar pada member yang mengikuti program tersebut selama enam bulan dan setelah itu member tersebut berhak datang kapan saja ke cafe Mindset English Cafe untuk mengaplikasikan ilmu yang didapatkan dalam kelas selama enam bulan. Hal ini sebagaimana yang dipaparkan beberapa official Mindset English Center Parepare sebagai berikut :

Semua peserta kursus seumur hidup diberikan rancangan kerja selama satu tahun pertama dengan enam bulan belajar how to speak well, sedangkan enam bulan selanjutnya belajar tata bahasa di cafe Mindset English Cafe (MEC) mengaplikasikan apa yang mereka dapatkan pada enam bulan pertama di kelas. Kalau pun mereka belum mampu menguasai dan mengaplikasikan apa yang telah diajarkan oleh trainer maka akan ditambah lagi satu tahun sampai seterusnya higgah mereka betulbetul mampu dan cakap dalam Berbahasa Inggris. ${ }^{26}$

Metode yang digunakan dalam program kursus seumur hidup adalah memberikan pelayanan berupa pembelajaran Bahasa Inggris selama satu tahun pertama, di mana dalam satu tahun dibagi menjadi dua, enam bulan pertama belajar grammar dan speaking di kelas dibimbing oleh pengajar kelas, setelah itu enam bulan selanjutnya belajar speaking di cafe dan dibimbing oleh pengajar cafe bukan pengajar kelas lagi. Dan apabila dalam satu tahun ini peserta belum mampu berbahasa Inggris maka akan ditambah satu tahun lagi sampai seterusnya hingga mereka mampu. ${ }^{27}$

Metodenya dilakukan di kelas dan di cafe, di kelas member atau peserta diajar selama enam bulan dan enam bulan lagi di cafe. ${ }^{28}$

Menggunakan konsep free class. Dalam artian tidak terikat pada waktu regular atau kelas dan dilaksanakan dengan suasana santai di cafe. ${ }^{29}$

Program kursus seumur hidup memiliki daya tarik tersendiri dan berbeda dari program kursus Bahasa Inggris pada umumnya, sebagaimana hasil wawancara dengan beberapa members Mindset English Center Parepare, sebagai berikut :

Program kursus seumur hidup sangat baik kerena dengan program tersebut member dapat terus belajar dan belajar untuk menguasai Bahasa Inggris tanpa batasan waktu seperti tempat kursus lainnya. ${ }^{30}$

Saya memili kursus seumur hidup di MEC karena saya merasa program kursus seumur hidup MEC memiliki banyak kelebihan dibanding tempat kursus lain. ${ }^{31}$

\footnotetext{
${ }^{24}$ Hasil Wawancara Ms. Dian Ekawati, selaku Member Mindset English Center Parepare, Tanggal 12 Juli 2017.

${ }^{25}$ Hasil Wawancara Mr. Adam Haq, selaku Member Mindset English Center Parepare, Tanggal 12 Juli 2017.

26.Hasil Wawancara Mr. Hadi Arif, selaku Branch Manager Mindset English Center Pinrang, Tanggal 12 Juli 2017.

${ }^{27}$ Hasil Wawancara Mr. Adri Aladin, selaku Branch Manager Mindset English Center Parepare, Tanggal 12 Juli 2017.

${ }^{28}$ Hasil Wawancara Ms. Arifa Apriani, selaku Trainer Mindset English Center Parepare, Tanggal 12 Juli 2017.

${ }^{29}$ Hasil Wawancara Mr. Muh. Kasim, selaku Trainer Mindset English Center Parepare, Tanggal 12 Juli 2017.

${ }^{30}$ Hasil Wawancara Ms. Putri Safira Hamid, selaku Member Mindset English Center Parepare, Tanggal 12 Juli 2017.

${ }^{31}$ Hasil Wawancara Ms. Annita Dauli, selaku Member Mindset English Center Parepare, Tanggal 12 Juli 2017.
} 
Saya memili kursus seumur hidup di MEC karena banyak keuntungan yang saya dapatkan, yaitu: MEC tidak memiliki batasan waktu untuk member, mendapatkan kartu member yang dapat digunakan di cabang bimbingan kursus seumur hidup MEC manapun yang ada di Indonesia, sistem belajar lebih santai dan menyenangkan, trainer MEC selalu selalu mengadakan games setiap akhir perstemuan di kelas sehingga tidak membuat jenuh dan bosan, dapat menyelesaikan pekerjaan rumah (pr) ditempat dengan bantuan trainer yang ada. ${ }^{32}$

Dari hasil wawancara di atas program kursus seumur hidup Mindset English Center Parepare memiliki kelebihan. Kelebihan program ini membantu dan meringankan beban biaya member, sehingga member lebih dituntun serius dalam pembelajaran Bahasa Inggris. Ketika keluar daerah member dapat menggunakan kartu member di daerah mana saja selama di daerah tersebut terdapat cabang Mindset English Center.

Berdasarkan hasil wawancara di atas jika dikaitkan dengan manajemen syariah telah sesuai, karena program ini dapat memudahkan dan meringankan biaya kursus Bahasa Inggris. Dalam hal ini pemeliti mengkaji dari segi manajemen syariah, di mana program ini harus dijalankan sesuai dengan apa yang direncanakan dan memerlukan rasa tanggujawab yang tinggi.

Semua organisasi, baik yang berbentuk badan usaha swasta, badan yang bersifat publik ataupun lembaga-lembaga sosial kemasyarakatan tentu menpunyai suatu tujuan tersendiri yang merupakan motivasi dari pendiriannya. Manajemen dalam suatu badan usaha, baik industri, niaga dan jasa didorong oleh motif pendapatan keuntungan (profit). Untuk mendapatkan keuntungan yang besar, manajemen haruslah diselenggarakan dengan efisien. ${ }^{33}$

Manajemen yang kita kenal sekarang ini adalah manajemen Barat yang individualistis dan kapitalistis. Di dalam masyarakat yang individualistis, kepentingan bersama dapat ditangguhkan demi kepentingan diri sendiri. Hal ni disebabkan karena mereka telah meninggalkan nilai-nilai religius yang berdasarkan hubungan tanggung jawab antar manusia dengan Tuhannya, baik mengenai suruhan yang ma'ruf dan pencegahan yang mungkar, semata-mata ditujukan untuk memenuhi kebutuhannya. ${ }^{34}$

Dalam manajemen syariah dirumuskan suatu pengelolaan untuk memperoleh hasil optimal yang bemuara pada pencarian keridhaan Allah. Ada empat prinsip (aksioma) dalam ilmu ekonomi Islam yang mesti diterapkan dalam bisnis syari'ah, yaitu: Tauhid (unity), keseimbangan atau kesejajaran (equilibrium), kehendak bebas (free will) dan tanggung jawab (responsibility). ${ }^{35}$

\section{a. Tauhid (unity)}

Alam semesta, termasuk manusia, adalah milik Allah, yang memiliki kemahakuasaan (kedaulatan) sempurna atas mahkluk-mahkluknya. Konsep tauhid, yang merupakan suatu dimensi vertikal Islam dipahami sebagai suatu ungkapan keyakinan seorang Muslim atas keesaan Tuhan. Konsep tauhid memberikan prinsip perpaduan yang kuat sebab seluruh umat manusia dipersatukan dalam ketaatan

\footnotetext{
${ }^{32}$ Hasil Wawancara Mr. Abu Dilla Husain, selaku Member Mindset English Center Parepare, Tanggal 12 Juli 2017. ${ }^{33}$ Muhammad, Manajemen Bank Syariah, h. 193.

${ }^{34}$ Muhammad, Manajemen Bank Syariah, h. 193.

${ }^{35}$ Isnaniayuniaa,Makalah Manajemen Syariah, http://isnaniayuniaa.blogspot.co.id/2015/03/.ht (20 April 2017).
}

Banco, Volume 1, November 2019 


\section{Rubiah, Moh. Yasin Soumena, Abdul Hamid}

kepada Allah semata. Dari konsep ini, Islam menawarkan keterpaduan agama, ekonomi, dan sosial demi membentuk kesatuan ${ }^{36}$.

Program kursus seumur hidup Mindset English Center Parepare menunjukkan sikap akidah karena dapat membantu dalam hal meringankan dan tidak menjadikan biaya sebagai beban dalam menuntut ilmu dan mampu melaksanakan keseimbangan sepenuhnya terhadap member atas apa yang memjadi hak penuh.

\section{b. Keseimbangan dan Kesejajaran (Equilibrium)}

Kesimbangan atau 'adl, menggambarkan dimensi horizontal ajaran Islam dan berhubungan dengan harmoni segala sesuatu di alam semesta. Islam telah mengharamkan setiap hubungan bisnis atau usaha yang mengandung kedzaliman dan mewajibkan terpenuhinya keadilan yang teraplikasikan dalam hubungan usaha dan kontrak- kontrak serta pejanjian bisnis.

Dalam beraktifitas di dunia bisnis, Islam mengharuskan berbuat adil yang diarahkan kepada hak orang lain, hak lingkungan sosial, hak alam semesta. Jadi, keseimbangan alam dan keseimbangan sosial harus tetap terjaga bersamaan dengan operasional usaha bisnis. Allah SWT berfirman dalam Q.S anAam/06: 152.

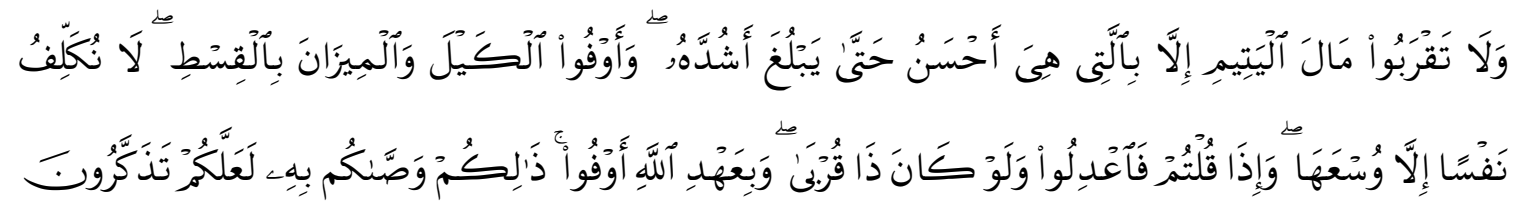

Terjemahnya:

Dan janganlah kamu dekati harta anak yatim, kecuali dengan cara yang lebih bermanfaat, hingga sampai ia dewasa. dan sempurnakanlah takaran dan timbangan dengan adil. kami tidak memikulkan beban kepada sesorang melainkan sekedar kesanggupannya. dan apabila kamu berkata, Maka bendaklab kamu berlaku adil, kendatipun ia adalah kerabat(mu), dan penubilah janji Allah. yang demikian itu diperintabkan Allah kepadamu agar kamu ingat. ${ }^{37}$

\section{c. Kehendak Bebas (Free Will)}

Konsep free will merupakan kebebasan yang diberikan kepada manusia untuk melakukan sesuai apa yang diinginkan tanpa adanya paksaan, akan tetapi manusia yang baik akan menggunakan kebebasan tersebut dalam rangka tauhid dan keseimbangan. ${ }^{38}$

Konsep kehendak bebas berkedudukan sama dengan konsep kesatuan dan keseimbangan. Setiap hal yang dilakukan di dunia kita harus tunduk dengan aturan-aturan yang ditetapkan oleh Allah SWT demi kehidupan pribadi dan kehidupan sosial, agar tidak terjadi konflik dalam diri sendiri dan orang lain.

Program kursus seumur hudup Minset English Center Parepare dapat dikatakan memberikan kehendak bebas, karena aktifitas belajar yang tidak terikat oleh waktu namun tetap efisien dan efektif.

\footnotetext{
${ }^{36}$ Muhammad Majdy Amiruddin, 'SYAIBANI ECONOMIC THOUGHT ON AL-KASB', Rausyan Fikr: Jurnal Studi Ilmu Ushuluddin Dan Filsafat, 15.1 (2019), 85-111.

${ }^{37}$ Kementerian Agama RI, Al-Qur'an dan Terjemahannya, h. 149.

38 Sofyan S. Harahap, Etika Bisnis dalam Perspektif Islam (Jakarta: Salemba Empat, 2011), h. 78.
} 


\section{d. Bertanggung Jawab (Responsibility)}

Untuk memenuhi konsep keadilan dan kesatuan seperti yang kita lihat dalam ciptaan Allah SWT manusia harus bertanggungjawab terhadap segala tindakannya. Dalam usaha bisnis, konsep tanggungjawab merupakan niat dan iktikad yang perlu diperhatikan terkait pengelolaan sumber daya alam dan sumber daya manusia secara makro, maupun dalam menjalankan suatu perusahaan.

Motode yang diterapkan dalam menjalankan program kursus seumur hidup membutuhkan rasa tanggungjawab penuh dari all official, memberikan pelayanan sebaik mungkin, menyajikan dan menyesuaikan materi dengan member karena member memiliki kemampuan yang berbeda-beda.

\section{Evaluasi Strategi Mindset English Center Parepare dalam Pencapaian Tujuan}

Evaluasi merupakan tahap akhir dalam manajemen strategis, di mana evaluasi sebagai suatu tindakan atau proses mengukur kemajuan, menunjang penyusunan rencana, serta memperbaki atau melakukan penyempurnaan kembali terhadap perencanaan perusahaan. Evaluasi adalah kegiatan atau proses untuk mengukur dan selanjutnya menilai, sampai manakah tujuan yang telah dirumuskan sudah dapat dilaksanakan. Apabila tujuan yang telah dirumuskan itu direncanakan untuk dicapai secara bertahap, maka dengan evaluasi yang berkesinambungan akan dapat dipantau, tahapan manakah yang sudah dapat diselesaikan dan mana pula tahapan yang mengalami kendala dalam pelaksanaan.

Dalam program kursus seumur hidup, Mindset English Center Parepare yang telah berjalan selama kurang lebih dua tahun memperoleh hasil yang memuaskan, terbukti dari jumlah member yang mengikuti program bersebut sudah mencapai tiga ratus orang. Dengan kata lain, hasil evaluasi ternyata menggembirakan, sebab tujuan yang telah ditentukan telah dapat dicapai sesuai dengan yang direncanakan. Sebaimana hasil wawancara dengan salah satu trainer Mindset English Center Parepare, sebagai berikut :

Program ini sudah berjalan kurang lebih dua tahun semenjak MEC hadir di Kota Parepare. Hasilnya memuaskan, program ini cukup diminati terbukti dari jumlah member sekarang sekitar tiga ratus orang. ${ }^{39}$

Selain program kussus yang menarik, Mindset English Center Parepare juga memberikan kesempatan kerja kepada member yang dianggap sudah mampu dan layak mengajarkan Bahasa Inggris menjadi tutor atau trainer di Mindset English Center Parepare. Sebagaimana wawancara dengan Branch Manajer Mindset English Center Parepare Ms. Adri Aladin dan salah satu peserta atau member yang berhasil mendapatkan peluang kerja Mindset English Center Parepare, sebagai berikut :

Bagi mereka yang telah menyesaikan masa pembelajaran selama satu tahun dan dianggap mampu dan berkompeten dalam Bahasa Inggris berpeluang menjadi trainer di Mindset English Center Parepare. Sejauh ini ada empat sampai tujuh orang yang berhasil dan diangkat menjadi trainer Mindset English Center Parepare. ${ }^{40}$

"Saya sangat merasa diuntungkan menjadi member Mindset English Center Parepare, kegigihan mengikuti pembelajaran di program kursus seumur hidup telah saya nikmati hasilnya. Saya telah mampu berbagi ilmu Bahasa inggris dengan member lain. Yang dulunya berstatus member Mindset English Center Parepare sekarang menjadi trainer Mindset English Center

\footnotetext{
${ }^{39}$ Hasil Wawancara Ms. Nismawati, selaku Trainer Mindset English Center Parepare, Tanggal 12 Juli 2017.

${ }^{40}$ Hasil Wawancara Mr. Adri Aladin, selaku Branch Manager Mindset English Center Parepare, Tanggal 12 Juli 2017.
} 


\section{Rubiah, Moh. Yasin Soumena, Abdul Hamid}

Parepare. Alhamdulillah disemester enam ini saya mempu membayar kuliah saya sendiri. Ini berkat kursus seumur hidup. ${ }^{41}$ "

Tolak ukur berhasilnya suatu perusahaan dalam pencapaian tujuan juga dapat dinilai dari pandangan pelanggan terhadap apa yang ditawarkan perusahaan, mengamati tingkat kepuasan pelayanan yang didapatkan, dalam literatur manajemen islam dijumpai konsep pelayanan, seperti halnya hasil wawancara dengan beberapa member Mindset English Center Parepare, sebagai berikut:

"Saya puas dengan apa yang telah saya dapatkan di MEC Parepare, banyak yeng sebelumnya tidak saya dapatkan di kampus, saya dapatkan di program kursus seumur hidup". ${ }^{42}$

"Selama saya kursus di MEC, saya banyak mendapatkan Vocab (kosa kata) baru, kemudian materi yang didapatkan lansung diaplikasikan sehingga gampang dipahami”. ${ }^{43}$

“Alhamdulillah `... saya puas karena para tentor Mindset English Center Parepare sangat menyenangkan dan ramah". ${ }^{44}$

Dari hasil wawancara di atas, dapat ditarik kesimpulan bahwa pelaksanaan strategi yang dilakukan Mindset English Center Parepare pada produk program kursus seumur hidup sudah efektif dan efisien. Al-Baqarah ayat 195 menjelaskan bahwa Allah memerintahkan kita untuk melakukan perbuatan ihsan (baik), karena Allah mencintai orang-orang yang berbuat baik. Firman Allah Q.S. Al-Baqarah/02: 195.

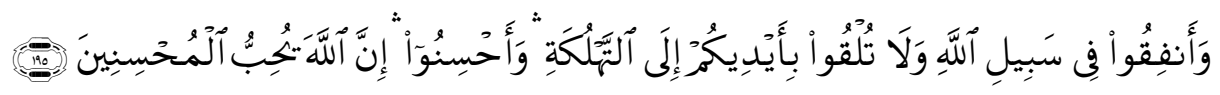

Terjemahnya :

Dan belanjakanlah (harta bendamu) di jalan Allah, dan janganlah kamu menjatubkan dirimu sendiri ke dalam kebinasaan, dan berbuat baiklah, Karena Sesunggubnya Allah menyukai orang-orang yang berbuat baik. ${ }^{45}$

Perintah berbuat baik juga dijelaskan dalam surah an-Nahl ayat 90. Sebaimana firman Allah Q.S. AnNahl/16: 90.

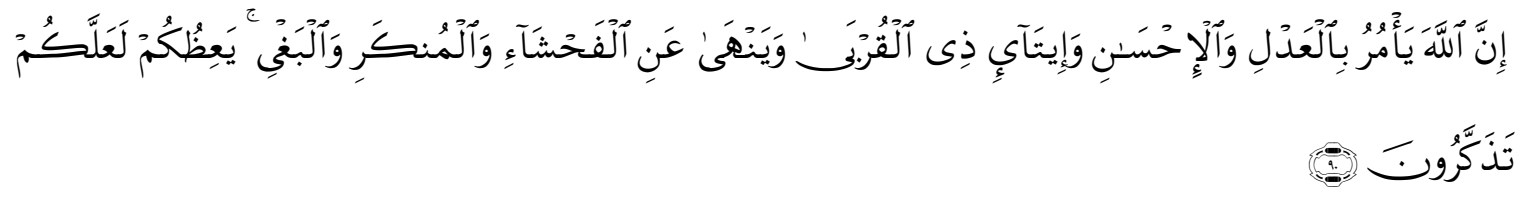

Terjemahnya :

Sesungguhnya Allah menyuruh (kamu) berlaku adil dan berbuat kebajikan, memberi kepada kaum kerabat, dan Allab melarang dari perbuatan keji, kemungkaran dan permusuhan. dia memberi pengajaran kepadamu agar kamu dapat mengambil pelajaran. ${ }^{46}$

\footnotetext{
${ }^{41}$ Hasil Wawancara Ms. Nisa Hidaya, selaku Member Mindset English Center Parepare, Tanggal 12 Juli 2017.

${ }^{42}$ Hasil Wawancara Ms. Hera Adira, selaku Member Mindset English Center Parepare, Tanggal 12 Juli 2017.

${ }^{43}$ Hasil Wawancara Ms. Sri Wahyuni, selaku Member Mindset English Center Parepare, Tanggal 12 Juli 2017.

${ }^{44}$ Hasil Wawancara Mr. Yusran, selaku Member Mindset English Center Parepare, Tanggal 12 Juli 2017.

${ }^{45}$ Kementerian Agama RI, Al-Qur'an dan Terjemahannya, h. 30.

${ }^{46}$ Kementerian Agama RI, Al-Qur'an dan Terjemabannya, h. 138.
} 
Ayat di atas menegaskan bahwa islam membenarkan setiap kegiatan yang bersifat positif dan menolong serta memberikan manfaat baik termasuk dalam kegiatan ekonomi.

Dalam perspektif islam, tujuan manajemen merupakan salah satu bentuk kegiatan melalui proses dan prosedur tertentu untuk mencapai tujuan akhir secara maksimal dengan bekerjasama mencapai tujuan utama. Artinya untuk mencapai tujuan menejemen tidak hanya berfokus kepada manusia sebagai manajer dan anggota pelaksana lain sebagai defisi manajemen, tetapi juga itu juga memerlukan saranasarana lain yang erat hubungannya dengan pencapaian tujuan. Sarana-sarana tersebut meliputi men, monay, material, methods dan market

\section{Kesimpulan}

1. Perencanaan strategi Mindset English Center Parepare dalam pencapaian tujuan menerapkan program kursus seumur hidup yang memudahkan peserta dari segi pembayaran, sehingga dapat menolong dan meringankan beban member. Hal ini sesuai dengan prinsip manajemen syariah yakni prinsip keadilan dan tolong menolong.

2. Implementasi strategi Mindset English Center Parepare dalam pencapaian tujuan adalah menjalangkan program kursus seumur hidup hingga member dianggap mampu berbahasa Inggris. Hal ini sesuai dengan prinsip manajemen syariah yakni prinsip amanah dan pertanggungjawaban.

3. Evaluasi strategi Mindset English Center Parepare dalam pencapaian tujuan mencapai hasil yang efektif dan efisien. Terbukti dari banyak jumlah peserta dan berjalannya program kursus seumur hidup Mindset English Center Parepare hingga sekarang. Prespektif manajemen syariah terhadap strategi Mindset English Center Parepare dianggap sesuai dengan prinsip-prinsip manajemen syariah. 


\section{Rubiah, Moh. Yasin Soumena, Abdul Hamid}

\section{Daftar Pustaka}

\section{Buku}

Alama. 2013. Manajemen Pemasaran dan Pemasaran Jasa edisi 2. Bandung: Alfabeta.

Al-Haji, Abdullah Siddiq al-Haji. 2005. Inti Dasar Hukum Dagang Islam. cet. 1; Jakarta: Balai Pustaka.

Ali, Zainuddin. 2008. Metode Penelitian Hukum. Jakarta: Sinar Grafika Basrowi.

Assauri, Sofjan. 2014. Manajemen Pemasaran. Jakarta: PT Raja Grafindo Persada.

Budiman, Ahmad Nasir dan Mujibah Utami. 1998. Islam Sifat, Prinsip Dasar dan Jalan Menuju Kebenaran, Cet 1; Yogyakarta: Dana Bhakti Prima.

Bungin, Burhan. 2012. Analisis Data Penelitian Kualitatif. Jakarta: PT RajaGrafindo Persada.

Damin, Sudarman. 2012. Menjadi Penelti Kualitatif; Ancangan Metedologi, Presentasi dan Publikasi Hasil Penelitian Untuk. Mahasiswa dan Peneliti Pemula Bidang Ilmu-Ilmu Sosial, Pendidikan dan Humaniora. Bandung: CV Pustaka Setia.

Deliarnov. 2012. Perkembangan Pemikiran Ekonomi. Jakarta: PT Raja Grafindo Persada.

Departemen Agama RI. 2010. Al-Qur'an dan Terjemabnya. Bandung: CV Penerbit Diponegoro.

Hadikusuma, Hilmah. 2005. Metode Pembuatan Kertas Kerja Atau Skripsi Ilmu Hukum. Bandung: Alpabeta.

Hafidhuddin, Didin dan Hendri Tanjung. 2003. Manajemen Syariab dalam Praktik. Jakarta: Gema Insani Prees.

Kasmir. 2008. Pemasaran Bank. Jakarta: Kencana.

Kotler, Philip. 2000. Manajemen Pemasaran. Jakarta: PT. Indeks Kelompok Gramedia.

Kotlet dan Keller. 2009. Manajemen Pemasaran Jilid 1 edisi 13. Jakarta: Erlangga.

Manan, Abdul. 2009. Hukum Ekonomi Syariah dalam Perspektif Kewenangan Peradilan Agama. Jakarta: PT Raja Grafindo Persada.

Moleong, Lexy J. 2010. Metodologi Penelitian Kualitatif. Bandung: PT Remaja Rosdakarya.

Muhammad. 2005. Manajemen Bank Syariah. Yogyakarta, Unit Penerbit dan Percetakan UPP AMP YKPN.

Muhammad Majdy Amiruddin, 'SYAIBANI ECONOMIC THOUGHT ON AL-KASB', Rausyan Fikr: Jurnal Studi Ilmu Ushuluddin Dan Filsafat, 15.1 (2019), 85-111. 
Muis, Saludein. 2007. Pemikiran Teori Organisasi dan Manajemen. Yogyakarta: Penerbit Graha Ilmu.

Najed, Nasri Hamang. 2013. Ekonomi Islam (Zakat Ajaran Kesejabteraan dan Keselamatan Umat. Parepare: STAIN Parepare.

Pusat pengkajian dan Pengembangan Ekonomi Islam (P3EI). 2008. Ekonomi Islam. Jakarta: PT Raja Grafindo Persada.

Pusat Pengkajian dan Pengembangan Ekonomi Islam. Ekonomi Islam. Cet. Ke-4; Jakarta: PT Rajagrafindo Persada.

Robbins, Stephen P. dan Mary Coulter. 2013. Manajemen Edisi Kesepuluh Jilid 1. Jakarta: PT. Gelora Aksara Pratama.

Sholihin, Ismail. 2009. Pengantar Manajemen. Jakarta: PT. Gelora Aksara pratama.

Sule, Ernie Tisnawati dan Kurniawan Saefullah. 2012. Pengantar Manajemen. Jakarta: Kencana Perdana Media Group.

Suwandi. 2010. Memahami Penelitian Kualitatif. Jakarta: Rineka Cipta.

Tim Penyusun. 2013. Pedoman Penelitian Karya Ilmiah (Makalah dan Skripsi). Edisi Revisi. Parepare: STAIN Parepare.

Tjiptomo, Fandy. 2008. Strategi Pemasaran. Yogyakarta: Penerbit Andi.

Umar, Husain. 2010. Strategic Manajemen In Action. Jakarta: Kencana Perdana Media Group.

Vellas, Francios dan Lionel Becherel. 2008. Pemasaran Parinisata Internasional: Sebuah Pendekatan strategis. Jakarta: Yayasan Obor Indonesia.

Wahyudi, Agustinus Sri. 2010. Manajemen Strategik Pengantar Proses Berpikir Strategik. Jakarta: Binarupa Aksara.

Yusanto, Ismail dan M. Arif Yunus. 2009. Pengantar Ekonomi Isalam. Bogor: Al-Azhar Press.

Yusanto, Muhammad Ismail dan Muhammad Karebet Widjajakusuma. 2002. Menggagas Bisnis Islam. Jakarta: Gema Insani.

Zuriah, Nurul. 2007. Metodologi Penelitian Sosial dan Pendidikan Cet. II. Jakarta: PT Bumi Aksara.

\section{Internet}

http://isnaniayuniaa.blogspot.co.id/2015/03/.ht (diakses pada tanggal 20 April 2017). 


\section{Rubiah, Moh. Yasin Soumena, Abdul Hamid}

http://juwitaaroem.blogspot.co.id/2014/05/pentingnya-menguasai-bahasa-inggris.html?m=1 (diakses pada tanggal 01 April 2017).

https:// farnidaassignment.wordpreess.com/2012/10/13/pengantar-manajemen implementasi-strategi/. (diakses Tanggal 17 April 2017).

https:// fatihalam.blogspot.com/2011/11/evaluasi-strategi.html?m=1,(diakses Tanggal 17 April 2017).

https://id.m.wikepedia.org/wiki/Gaya hidup (diakses pada tanggal 01 April 2017).

\section{Sumber Skripsi}

Muchlis, Moh. Abdul. 2010. "Implementasi Manajemen Strategi dalam Upaya Peningkatan Mutu Pendidikan di Pondok Pesanteren darul Ulum Rejoso Peterongan Jombang Jawa Timur”. Skripsi Sarjana; Fakultas Dakwah: Jogyakarta.

Puspita, Elly. 2012. “Analisa Manajemen Strategi pada PT. Garuda Indonesia Berdasarkan Balanced Scorecard Tahun 2010-2011”. Skripsi Sarjana; Fakultas Ekonomi: Jogyakarta.

Rahmawati, Anisah. 2004. "Manajemen Starategi pada Lembaga Pendidikan Kursus Keterampilan dan Pelatihan Kerja (LPK) Karya Abadi Kec. Suruh”. Skripsi Sarjana; Universitas Kristen Satya wacana Salatiga 